Original Research Paper

\title{
Development of Production Technology for Meat Products using $\beta$ Carotene
}

\author{
Ainur Matibayeva*, Bagila Jetpisbayeva, Mira Serikkyzy, \\ Nurgul Batyrbayeva, Ainur Zheldybayeva and Gaukhar Kuzembayeva
}

Almaty Technological University, Almaty, Kazakhstan

\author{
Article history \\ Received: 23-07-2020 \\ Revised: 22-12-2020 \\ Accepted: 22-12-2020 \\ Corresponding Author: \\ Ainur Matibayeva \\ Almaty Technological \\ University, Almaty, \\ Kazakhstan \\ Email: matibayeva.ainur@bk.ru
}

\begin{abstract}
In this article, the possibility of using pumpkin in the production of meat products is investigated and justified. In order to improve the functional and technological properties of sausage, the recipe and production technology of cooked sausage using a natural source of beta carotene have been developed. Physical-chemical, functional-technological and organoleptic properties of the finished product were studied. The results of the study showed that with an increase in pumpkin pulp from 5 to $15 \%$, the content of $\beta$-carotene in the developed sausage products proportionally increases from $0.9 \mathrm{mg} / 100 \mathrm{~g}$ to $2.2 \mathrm{mg} / 100 \mathrm{~g}$. The highest content of $\beta$-carotene in cooked sausage with the introduction of pumpkin pulp in the proportion of $15 \%$, which is $44 \%$ of the daily intake of $\beta$ carotene. The nutritional value of the finished product is determined. The developed sausage products are products of reduced energy value. Values range from 180 to $189 \mathrm{kcal}$. The practical possibility of using plant bioactive agricultural raw materials in the production of cooked sausages has been proved, which allows us to expand the range of high-quality and functional meat products.
\end{abstract}

Keywords: Meat Processing, Technology, Functional Properties, Pumpkin, Nutritional Value

\section{Introduction}

As part of the implementation of the comprehensive program for the development of the agro-industrial complex 2017-2021, one of the main tasks facing food biotechnology is the development of qualitatively new food technologies that prevent the occurrence of certain diseases and reduce the burden on the medical sector. The Ministry of agriculture of the Republic of Kazakhstan has set a task to increase the export of processed products by 2.5 times. At the same time, against the background of explosive growth in live cattle exports, exports of meat and meat products directly lag behind. According to the statistics Committee, for 2019, the figure was only 26 thousand tons-a quarter more than a year earlier. Of them directly meat exported 22.6 million tons and the products of higher level processingsausages, canned meat, smoked meat and other thingsonly 3.4 thousand tonnes (the indicator went negative). During the same period, Kazakhstan imported nine times more meat and almost 15 times more meat products than it exported (203.2 thousand tons, meat products - 49.1 thousand tons). In such circumstances, the creation and implementation of innovative technologies in the production of products containing a wide range of biologically active compounds for specific purposes is of particular importance.

Meat and meat products lack vitamin $\mathrm{C}$, while $\mathrm{P}$ carotene and vitamin $\mathrm{E}$ are found in trace amounts (Rogov et al., 2008; Samchenko and Kalenik, 2012; Skurikhin and Tutelyan, 2008). In the process of technological processing of beef meat, vitamin $\mathrm{A}$ is destroyed, the content of thiamine is reduced by 2 times and the remaining amounts of vitamins no longer meet the physiological needs of the human body (Kosenko and Kalenik, 2017).

An effective way to solve this problem is to develop cooked sausages using functional ingredients based on a combination of meat and vegetable raw materials. Meat products, in particular, cooked sausage products, can be considered as a basic basis for creating products that have functional and technological properties that provide the human body with not only full-fledged protein, but also vitamins, minerals and dietary fibers 
through the use of bioactive agricultural plant raw materials (Karapetyan, 2015; Makangali et al., 2018; Ivanova et al., 2010).

Pumpkin pulp, which contains twice as much $\beta$-carotene (14.6 mg/100 g) as carrots $(7.3 \mathrm{mg} / 100 \mathrm{~g})$, can be used as a bioactive vegetable raw material (Antipov, 2006). It is known that $\beta$-carotene is an active participant in the biochemical processes in the human body, it has antioxidant, anti-carcinogenic, anti-mutagenic and immunostimulating properties. In addition, betacarotene is a precursor of vitamin A, which is necessary for the body to ensure normal vision, growth, development and the ability of humans and animals to reproduce. Pumpkin has a high content of ascorbic acid $(12.3 \mathrm{mg} / 100 \mathrm{~g})$, which is a good source of antioxidants for humans (Aslanova, 2010).

In addition to vitamins, pumpkin pulp contains bioactive carbohydrate dietary fibers and pectin that help prevent chronic intoxication and remove toxic elements, residual pesticides, radionuclides, nitrates and nitrites from the body (Magzumova, 2012; Tutelyan, 2012).

In connection with the above, the purpose of this work is to develop the recipe and technology of cooked sausage products based on beef with the addition of bioactive agricultural raw materials-pumpkin pulp.

\section{Materials and Methods}

The objects of research were used:

- $\quad$ Pumpkin of the "Smile" variety grown in Kazakhstan

- Model samples of minced systems with the addition of pumpkin pulp in selected dosages

- Samples of developed meat-growing cooked sausages

As an object for enrichment (control sample) was selected boiled sausage "Beef".

Preparation of model stuffing systems. In the cutter, the raw materials offered according to the recipe for cooking cooked "Beef" sausage are crushed.in the process of cutting, peeled and cut into pieces pumpkin is added along with crushed ice.
The study of physical and chemical quality indicators (mass fraction of protein, fat, moisture, sodium nitrite, table salt, carotenoids) of samples of vegetable sausages was carried out according to generally accepted methods in Kazakhstan (state standard 51479-99 (2007) Meat and meat products. Method for determining the mass fraction of moisture; state standard 54058-2010 (2011) functional food Products; state standard 21237-75 (2007) Meat. Methods of bacteriological analysis; state standard 230422015 (2016) Meat and meat products. Methods for determining fat-1; state standard 25011-81 (2006) Meat and meat products. Methods for determining protein).

Functional and technological properties of model stuffing systems were characterized by the total content of moisture-binding, water-retaining and fat-retaining abilities (Antipova et al., 2004).

A 5-point scale of organoleptic evaluation according to state standard 9959-91 was used to evaluate organoleptic indicators of sausage products quality.

Microbiological safety indicators were determined according to state standard 21237-75.

\section{Results and Discussion}

In order to determine the level of the vegetable component in the recipe of beef cooked sausage, the proportions of $5,10,15 \%$ of pumpkin flesh were initially selected, which was introduced into the meat system instead of the same water content. Pumpkin flesh was introduced at the stage of minced meat preparation at the rate of: Pumpkin flesh-in the proportion of 2.5, 5.0 and $7.5 \mathrm{~kg}$. Taking into account the enriching additive, $27.19 ; 24.69 ; 22.19 \mathrm{~kg}$ of water with ice were added to the recipe, respectively.

To develop a recipe for meat-growing sausages (Table 1) the recipe for boiled sausage "Beef" was taken as a basis.

We have studied the effect of pumpkin pulp on the functional and technological properties of the meat system. The results of the influence on the change in the moisture binding capacity of model minced meat are shown in Fig. 1.

Table 1: Recipe of model samples of sausage products $(\mathrm{kg} / 100 \mathrm{~kg})$

\begin{tabular}{|c|c|c|c|c|c|}
\hline \multirow[b]{2}{*}{$\underline{\text { Raw }}$} & \multicolumn{3}{|c|}{ Weight of pumpkin pulp, kg } & \multirow{2}{*}{$\begin{array}{l}\text { Spices, seasonings } \\
\text { and additives }\end{array}$} & \multirow[b]{2}{*}{ Weight, $\mathrm{kg}$} \\
\hline & $5 \%$ & $10 \%$ & $15 \%$ & & \\
\hline Tendon removed beef of the highest grade & 35.50 & & & Table salt & 0.57 \\
\hline Cored beef of 1 grade & 14.20 & & & Nitrite salt & 0.71 \\
\hline Fat beef & 17.75 & & & Sugar or glucose & 0.12 \\
\hline Egg powder & 0.71 & & & Black pepper & 0.12 \\
\hline Pumpkin & 2.50 & 5.00 & 7.50 & Ground allspice & 0.12 \\
\hline \multirow[t]{2}{*}{ Drinking water (with ice) } & 27.19 & 24.69 & 22.19 & Nutmeg & 0.04 \\
\hline & & & & Spices' & 0.51 \\
\hline TOTAL, kg & & & & 100,0 & \\
\hline
\end{tabular}




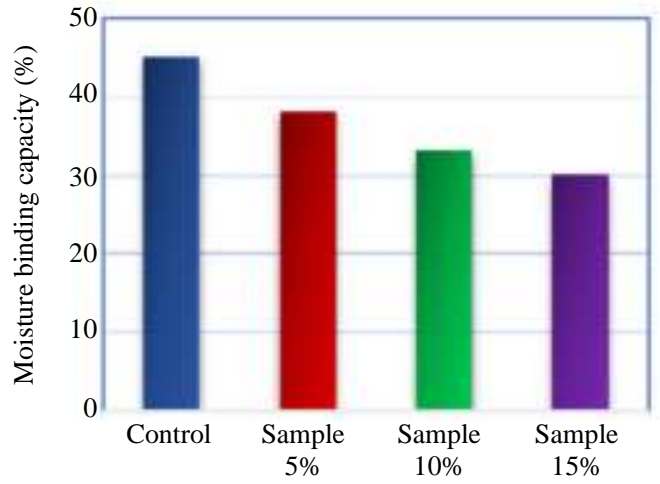

Model stuffing systems

E Control $\mathbf{n}$ Sample $5 \%$ Sample $10 \%$ Sample $15 \%$

Fig. 1: Moisture binding capacity of model minced meat

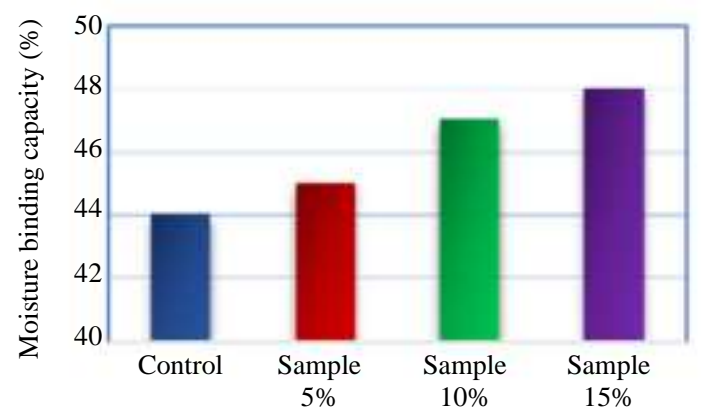

Model stuffing systems

Control

Sample $5 \%$ Sample $10 \%$

Sample $15 \%$

Fig. 2: Moisture-holding capacity of model minced meat

From the presented data, it is clear that adding pumpkin pulp reduces the moisture binding capacity of the model minced meat in relation to the control sample (42.8\%). The moisture binding capacity of minced meat with pumpkin in the proportion of 5 to $15 \%$ is reduced by $5.4-11.4 \%$, respectively, compared to the control sample. Adding 5\% of pumpkin pulp reduces the system's moisture binding capacity to $37.4,10$ to $33.2 \%, 15$ to $31.4 \%$.

The results of changes in the moisture retention capacity of model minced meat are shown in Fig. 2.

The presented results indicate that when adding pumpkin pulp to a model sample of sausage product, the moisture holding capacity of the minced meat increases. The moisture-retaining capacity of the test sample with the concentration of the introduced pumpkin pulp in the proportion of $5 \%$ increases by $1.28,10$ by $3.65 \%, 15$ by $4.16 \%$ in relation to the control sample $(44.06 \%)$.

The results of changing the fat-holding capacity of model minced meat are shown in Fig. 3.

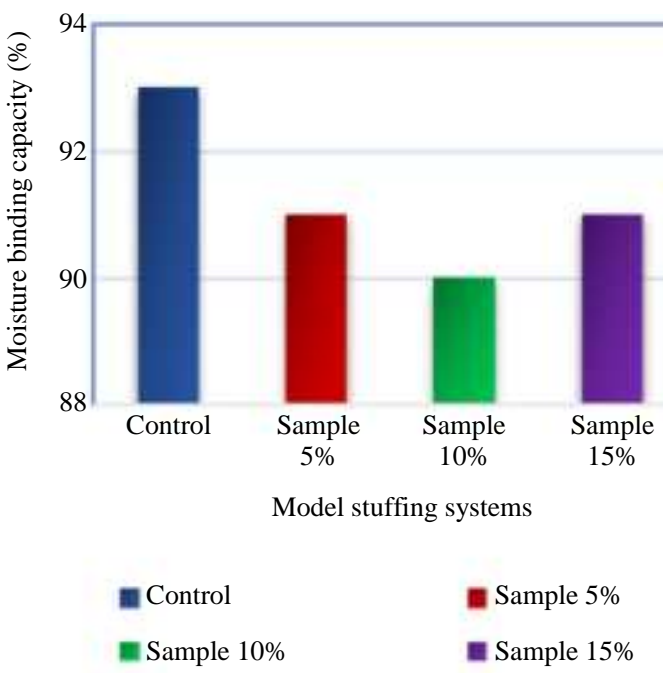

Fig. 3: Fat-holding capacity of model minced meat

When introducing pumpkin pulp into model minced meat, the fat-retaining capacity is reduced compared to the control sample (93.4\%). The addition of pumpkin pulp in the proportion of $10 \%$ reduces the system to the $89.9 \%$.

We determined the effect of pumpkin additives, introduced in the proportion of 5 to $15 \%$, on the organoleptic evaluation of model samples of sausage products. Ground beef was used as a control without adding a vegetable additive. The quality of minced systems was evaluated after heat treatment on a 5-point scale (Table 2).

Analyzing the results of organoleptic evaluation of experimental sausage products, it can be noted that all samples have a shade of taste, smell and color characteristic of the vegetable additive - pumpkin. It is shown that organoleptic indicators improve when adding pumpkin pulp in the proportion of 5 to $10 \%$ compared to the control sample ( 32.7 points). The sausage in the juiciness increases, the flavor becomes milder. When the additive was increased from 10 to $15 \%$, the smell and taste of pumpkin in the sausage became more pronounced and the yellow color on the sausage slices increased.

Thus, it was found that pumpkin pulp shows high water-absorbing and water-retaining properties in samples with the introduction of pumpkin pulp in the proportion of 10 and $15 \%$, which is important for regulating and forming the technological properties of minced systems.

Based on the research of technological and organoleptic properties of model meat systems, the proportion of introduced pumpkin pulp, which is $10 \%$ of the total mass of raw materials, was selected. In this content, the pumpkin additive shows its stabilizing properties when preparing the meat system.

A technological scheme for the production of sausage products with the addition of pumpkin additives has been developed, including the operations presented on Fig. 4. 
Table 2: Results of organoleptic evaluation of experimental sausage products Product rating on a 5 point scale

\begin{tabular}{lllllllll} 
Name & Appearance & Consistency & Split view & Color & Smell & Taste & Juiciness & Overall assessment \\
\hline Control sample & 4.8 & 5.0 & 4.8 & 4.8 & 4.8 & 4.8 & 4.1 & 32.7 \\
Sample \#1 (5\%) & 5.0 & 5.0 & 4.6 & 4.9 & 4.5 & 4.5 & 4.7 & 33.2 \\
Sample \#2 (10\%) & 4.4 & 4.9 & 4.9 & 4.5 & 4.6 & 4.6 & 4.9 & 32.8 \\
Sample \#3 (15\%) & 3.5 & 4.9 & 4.1 & 3.6 & 3.0 & 3.8 & 4.2 & 27.8 \\
\hline
\end{tabular}

Table 3: Physical and chemical indicators of cooked sausages

\begin{tabular}{llllll}
\hline Samples & Fat, \% & Moisture, $\%$ & Protein, \% & Salt, \% & Nitrite sodium, \% \\
\hline Control sample & 13.56 & 66.71 & 10.13 & 2.1 & 0.0034 \\
Sample №1 (5\%) & 13.62 & 67.32 & 10.56 & 2.15 & 0.0027 \\
Sample №2 (10\%) & 14.51 & 66.32 & 10.32 & 2.04 & 0.003 \\
Sample №3 (15\%) & 14.2 & 67.06 & 10.19 & 2.2 & 0.003 \\
\hline
\end{tabular}

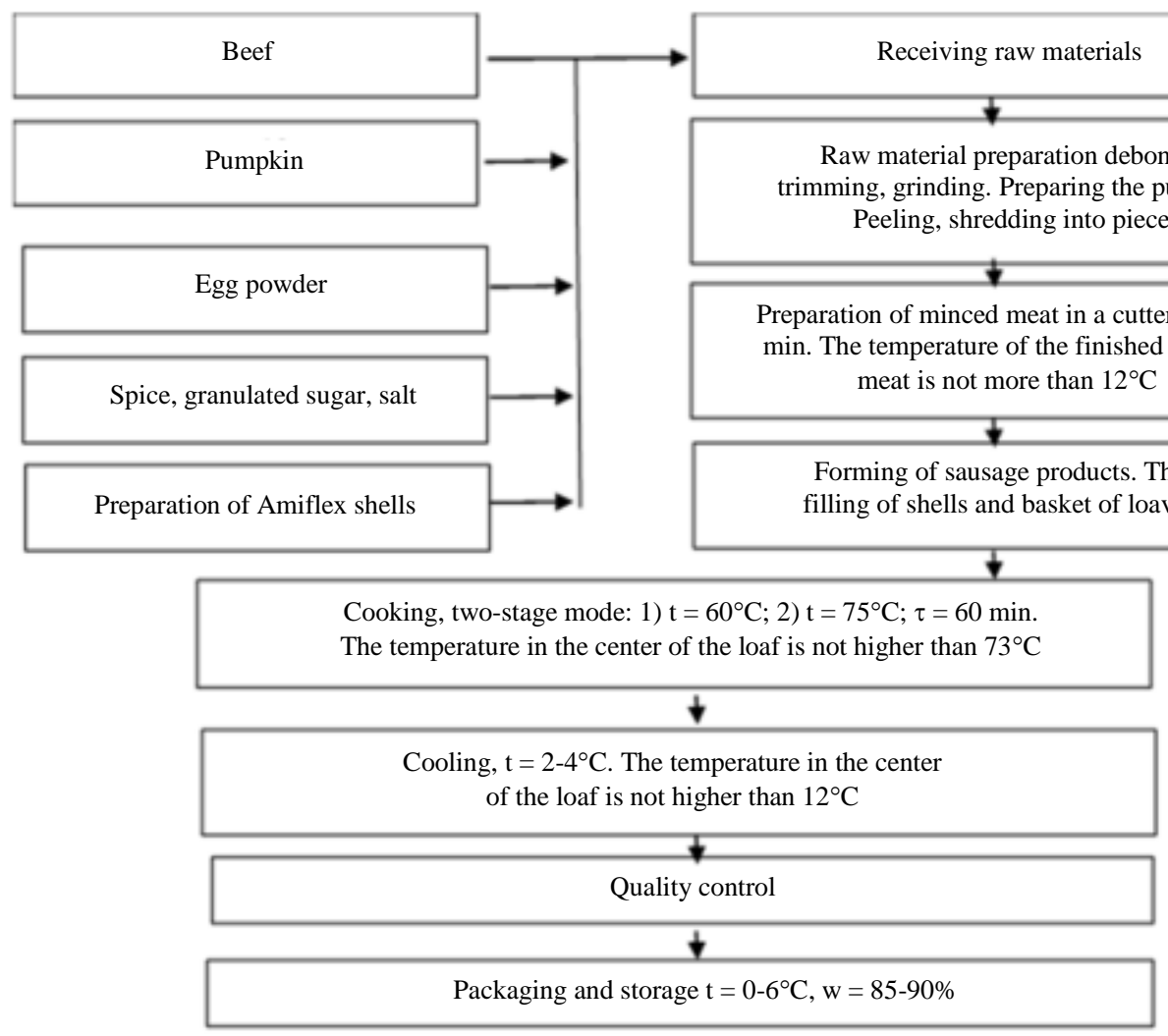

Fig. 4: Technological scheme of production of sausage products with pumpkin pulp

In accordance with the requirements for evaluating the quality of cooked meat products, a comprehensive study of cooked sausage products obtained using traditional technology and newly developed technology was conducted.

The results of the study of the quality of experimental and control sausage products are presented in Table 3.

From the presented data, it can be seen that in experimental samples of sausages with the addition of pumpkin, the moisture content increases to $67.3 \%$, fat $14.5 \%$, protein - to $10.56 \%$. The content of sodium chloride, both in the pilot sample and in the control sample, did not exceed the permissible values of TR CU 021/2011.

One of the most significant indicators of the quality of meat products is its residual content of sodium nitrite. Based on the data obtained, it can be seen that the residual content of sodium nitrite in the sausage with the addition of pumpkin is reduced in comparison with the control recipe. Based on this, it can be assumed that the biological components of pumpkin contribute to the biotransformation of sodium nitrite and reduce its content in the finished product. 


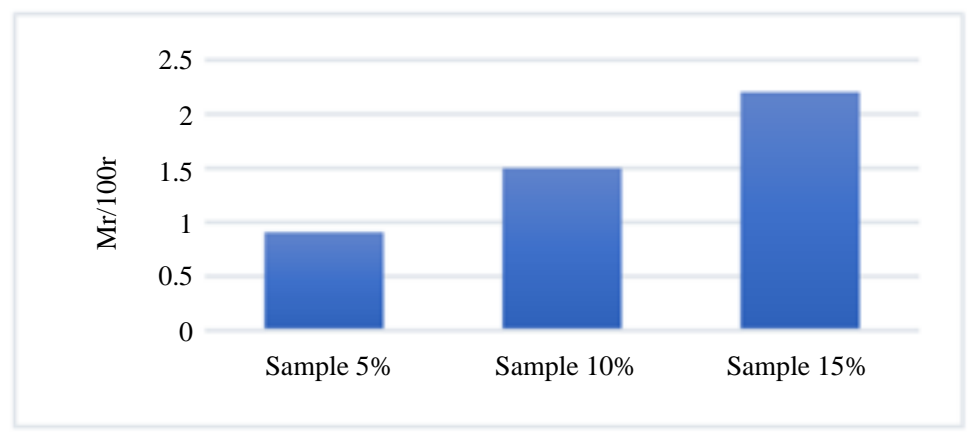

Fig. 5: $\beta$ carotene content in the developed sausage products

Table 4: Nutritional value of sausage products

\begin{tabular}{|c|c|c|c|c|}
\hline \multirow{2}{*}{$\begin{array}{l}\text { Cooked sausage product with } \\
\text { the addition of pumpkin }\end{array}$} & \multicolumn{4}{|c|}{ Indicators of nutritional value } \\
\hline & Protein, $\mathrm{g}$ & Fat, g & Carbohydrates, $\mathrm{g}$ & Energy value, $\mathrm{kcal} / \mathrm{kJ}$ \\
\hline $5 \%$ & 10.56 & 13.62 & 3.73 & $180 / 752.4$ \\
\hline $10 \%$ & 10.32 & 14.51 & 4.06 & $188 / 785.8$ \\
\hline $15 \%$ & 10.19 & 14.20 & 5.22 & $189 / 790.1$ \\
\hline
\end{tabular}

The degree of satisfaction of the average daily physiological needs of the human body in $\beta$-carotene with the use of $100 \mathrm{~g}$ of experimental samples of sausages was calculated. Figure 5 shows the content of the physiologically functional ingredient ( $\beta$-carotene) in the developed sausage products.

According to the recommended levels of dietary and biologically active substances, an adult should consume 5 $\mathrm{mg}$ of $\beta$-carotene daily. The results of the study showed that with an increase in pumpkin pulp from 5 to $15 \%$, the content of $\beta$-carotene in the developed sausage products proportionally increases from $0.9 \mathrm{mg} / 100 \mathrm{~g}$ to $2.2 \mathrm{mg} / 100$ g. The highest content of $\beta$-carotene in cooked sausage with the addition of pumpkin meat in the proportion of $15 \%$, which is $44 \%$ of the daily intake of $\beta$-carotene.

The nutritional and energy value of the developed sausage products is determined by calculation and is presented in Table 4. The Developed sausage products are products of reduced energy value. Values range from 180 to $189 \mathrm{kcal}$.

According to the results of microbiological studies conducted in the accredited food safety laboratory of Almaty technological University, the shelf life of cooked sausage with pumpkin in an AMIFLEX shell has been determined. The storage period is 45 days at a temperature from 0 to $5^{\circ} \mathrm{C}$.

\section{Conclusion}

The practical possibility of using plant bioactive agricultural raw materials in the production of cooked sausages has been proved, which allows us to expand the range of high-quality and functional meat products. In model experiments, the level of application of pumpkin pulp in the recipe of cooked sausage products is justified.
The proportion of pumpkin in the recipe should be $10 \%$ relative to the total weight of raw materials. The introduction of pumpkin pulp into minced meat helps to stabilize the technological properties of the product and allows you to obtain meat products that are close to the requirements for products with the inclusion of a functional ingredient. Cooked sausage with the addition of pumpkin pulp in a fraction of $10 \%$ satisfies $26 \%$ of the daily human need for $\beta$-carotene when it is consumed daily in the mass of $100 \mathrm{~g}$. The assessment of the quality and safety of the developed sausage products showed that the resulting products meet the standards of TR CU 021/2011 "on food safety".

\section{Acknowledgement}

This study was funded by the Ministry of Education and Science of the Republic of Kazakhstan

\section{Author's Contributions}

Ainur Matibayeva: Revised the manuscript, Conceived and planned the study.

Bagila Jetpisbayeva: Conceived and planned the study. Nurgul Batyrbayeva and Ainur Zheldybayeva: Conducted lab work and drafted the manuscript.

Mira Serikkyzy and Gaukhar Kuzembayeva: Did statistical analysis of data.

\section{Ethics}

This article is original and contains unpublished material. The corresponding author confirms that all of the other authors have read and approved the manuscript and there are no ethical issues involved. 


\section{References}

Antipov, V. A. (2006). Beta-carotene-value for the life of animals and birds, their reproduction and productivity. Krasnodar. 91. https://ur.bok.global/book/3165372/975698

Antipova, L. V., Glotova, I. A., \& Rogova, I. A. (2004). Methods of research of meat and meat products (Moscow: Kolos). http://padaread.com/?book=42066

Aslanova, M. A. (2010). Functional products based on meat, enriched with vegetable raw materials. Meat industry. $6, \quad 45-47$. https://www.elibrary.ru/item.asp?id=15218487

Ivanova, G. V., \& Kolman, O. Ya. (2010). Modeling of new types of meat-growing products. Siberian Bulletin of agricultural science. 8, 105-112.

Karapetyan, A. S. (2015). Change of biochemical composition of pumpkin fruits depending on storage time. Vegetable crops of Russia, (1), 48-51. https://www.elibrary.ru/item.asp?id=23376486

Kosenko, T. A., \& Kalenik, T. K. (2017). Method of modification of raw materials of animal origin for the enrichment of food systems. Bulletin of Krasnoyarsk state agrarian University. 1(124), 108-113.

Magzumova, N. V. (2012). Improving the technology of production of cooked sausages with the use of vegetable proteins. University news. Food technology. 2 (3), 58-60.

Makangali, K., Taeva, A., Lisitsyn, A., Uzakov, Y., Konysbaeva, D., \& Victoria, G. (2018). Study of the National Cooked Smoked Meat Products While Tests With Laboratory Animals at the Pathology Models With the Purpose to Confirm the Set of Biocorrective Features. Current Research in Nutrition and Food Science Journal, 6(2), 536-551.
Rogov, I. A., Zharinov, A. I., \& Voyakin, M. P. (2008). Chemistry of food. Principles of forming the quality of meat products. Moscow: RAPP. 340.

Samchenko, O. N., \& Kalenik, T. K. (2012). Use of pumpkin in the production of minced meat semifinished products. Engineering and technology food production. 25, 84-88.

Skurikhin, I. M., \& Tutelyan V. A. (2008). Tables of chemical composition and calorific value of Russian food products: Handbook. Moscow: Delhi print. 276.

State standard 21237-75. (2007). Meat. Methods of bacteriological analysis (with Changes $\mathrm{N} \mathrm{1,2}$ ). Moscow: $\quad$ standardinform. 28. http://docs.cntd.ru/document/1200021646

State standard 23042-2015. (2016). Meat and meat products. Methods for determining fat-1. 2017-0101. Moscow: standardinform. 8. http://docs.cntd.ru/document/1200133107

State standard 25011-81. (2006). Meat and meat products. Methods for determining protein. M.: standartinform. http://docs.cntd.ru/document/1200021660

State standard 51479-99. (2007). Meat and meat products. Method for determining the mass fraction of moisture. 2001-01-01. Moscow: standardinform. 30. http://docs.cntd.ru/document/gost-r-51479-99

State standard 54058-2010. (2011). Functional food Products. Method for determining carotinoidsIntroduction. 2012-01-01. Moscow: standardinform. 7. http://docs.cntd.ru/document/1200084966

State standard 9959-2015. (2010). Meat and meat products. General conditions for conducting an organoleptic assessment. Moscow: standardinform. 19. http://docs.cntd.ru/document/1200133106

Tutelyan, V. A. (2012). Chemical composition and calorific value of Russian food products: Handbook M: Delhi plus. 284. 